\title{
Dynamics, Degradation and Future Challenges of Wetlands in South Sumatra Province, Indonesia
}

\author{
Mustika Edi Armanto ${ }^{1, *}$, Elisa Wildayana ${ }^{1}$, and Bella Syakina ${ }^{1}$ \\ ${ }^{1}$ Faculty of Agriculture, Universitas Sriwijaya, South Sumatra, Indonesia
}

\begin{abstract}
This paperaims to analyzedynamics, degradation and future challenges of wetlands in South Sumatra Province, Indonesia. Research methods using Focus Group Discussion (FGD), research data and information are processedusing SPSS program. There are four dominant types of wetlands in South Sumatra, namely lebak swamps, tidal swamps, rivers, lakes, and peatlands. The area of lebakswamps has dominantly increased from year to year, while other wetlands have decreased extensively over the years. All species living in wetlands have decreased in number; the most dominant decline was experienced by fish, gymnosperm and fern and at least in moss and angiosperm. The main causes of wetlands degradation are weaken forcement and legal compliance of inadequate policies, reclamation and excessive drainage. Current efforts to protect the wetlands are restoration, groundwater control, fish population conservation and wetland reserves.
\end{abstract}

\section{Introduction}

Wetlands with an area of about 3.0 million ha occupy at least $30 \%$ of the total area of South Sumatra Province and mostlyislocated on the East coast of South Sumatra Province[1, 2]. Their uniqueness lies in relation to important twelve elements of the ecosystem, namely sea, beach or coastal, muddy plains, peatlands, lebak, lagoon, estuaries, lakes, rivers, islands, coastalforests and mangrove forests. The wetlands are capable of providing minimum $55 \%$ of ecosystem services, and have been severely degraded due to excessive reclamation, population pressures and weaken forcement and legal compliance of inadequatepolicies over the last 40 years. Healthy wetlands ecosystems play an important role in sustainable economic development[3].

Wetlands have been mostlyused for oil palm, rubber, fishery, livestock, food agriculture, industry, residential, recreation, shopping centers and others. Changes in the uses of wetlands are mostly due to human intervention [4], policies and concepts of wetlandsutilization planning, which are oftenundertaken for economicbenefitsonly[5-7]. Wetlandsenvironment aspects as a supporting media for human life are stillgettingless attention. At the present time the governmentistrying to restore and rehabilitate; trying to

${ }^{*}$ Correspondingauthor: mediarmanto@unsri.ac.id 
minimizewetlandsdegradation to a minimum level[8].Most wetlands are owned by individuals, private or local communitieswho are free to cultivatewithout regard to the environmental impacts of ecosystem balance. Plantation companies are licensed to cultivatetheir concession areas. They are free to cuttreesincluding mangroves and damage the naturaltreasures for economicdevelopmentactivities, such as shrimp and fish ponds [9, 10]. If this situation iscontinuallyallowed, itisfearedthatitwillnegatively impact the balance of the mangrove ecosystem, peatlands and wetlands as a whole[11].

From a positive point of view, systematic management is able to nurturebiodiversity in wetlands, in addition to contributingeconomically to the local population in particular and society at large. This paperaims to analyzedynamics, degradation and future challenges of wetlands in South Sumatra Province, Indonesia. This paperisexpected to beuseful as input for the government in makingpolicies for wetlands conservation and restoration. This paperisalso capable of providing a proportionalform of management in managingwetlands as well as management steps or strategies, constraints and future prospects of wetlands.

\section{Materials and Methods}

The studybelonged to the qualitative researchconducting in January to May 2018. The research areas are located in the whole South Sumatra Province, Indonesia. Around 100 respondentsweretaken by purposive sampling and interviewed by using semi-structured and face-to-face approach, consisting of open questions to enable perception developing.

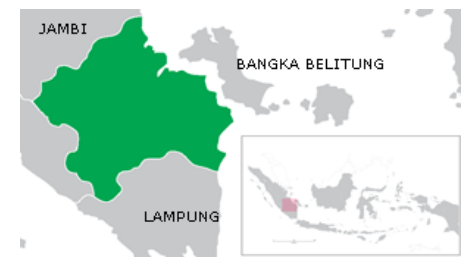

Fig. 1. Research location in South Sumatra Province (Source: Google)

Primarily research data were directly collected from respondents of local communities by using methods of Focus Group Discussion (FGD), in-depth study, field observation, direct interview. Data collecting from beneficiaries and stakeholders was done through governmental expert meetings; classrooms where students consist of public officials; projects obtained from private companies; activities of road shows; presentation of government and private seminars etc. Respondents from scientists and researchers were interviewed through presentations of national and international seminars; media appearance; recent appointments from key stakeholders. Secondary data were taken from research and research reports, and reviewing documents related to this research.

\section{Results and Discussions}

Wetlands are spread unevenly among the region of South Sumatra; namely (1) the South-Eastern region is dominated by lebak swamps (fresh water swamps) and peatlands; (2) various types of lakes, rivers and lebak swamps are found in the Western part; (3) the North East regions are dominated by tidal swamps, and rivers; (4) the Eastern region is dominated by tidal wetlands, rivers, peatlands; (5) Coastal areas are covered by tidal swamps, river estuaries, and swamp mud; (6) the middle region is covered by lebak 
swamps, river systems and lakes; (7) the lower parts of middle region is performed by the lake and river system; and (8) the most western region is occupied by lakes and groups of highland mountain (Figure 1).

\subsection{Dynamics of Wetlands in South Sumatra}

There are five types of dominant wetlands located in the South Sumatra Province region, namely lebak swamps, tides, rivers, lakes and peatlands. These five lands have undergone many changes in land area over the last 40 years. This changes occurs due to natural factors (i.e. forest and land fires, floods, earthquake, geologic tectonic) or human intervention (land conversion, economic development activities, and others. The wetland losses or expand over the last 40 years in South Sumatra is presented in Table 1.

Table 1. The wetland losses or expand over the last 40 years in South Sumatra.

\begin{tabular}{|c|c|c|c|}
\hline \multirow{2}{*}{ Wetland type } & \multicolumn{2}{|c|}{ Acreages of area (\%) } & \multirow{2}{*}{$\begin{array}{c}\text { Area losses or } \\
\text { expand (\%) }\end{array}$} \\
\cline { 2 - 3 } & $\mathbf{1 9 9 0}$ & $\mathbf{2 0 1 7}$ & +9.42 \\
\hline Lebak swamps & 30.55 & 33.43 & +6.70 \\
\hline Tidal swamps & 20.89 & 22.29 & +6.74 \\
\hline Rivers & 11.56 & 12.34 & +9.38 \\
\hline Lakes & 12.78 & 13.98 & -23.27 \\
\hline Peatlands & 13.45 & 10.32 & -29.06 \\
\hline Unidentified & 10.77 & 7.64 & -20.09 \\
\hline Total & 100.00 & 100.00 & \\
\hline
\end{tabular}

Source: Field survey results (2018), Landsat images (1992; 2017)

There are four types of wetlands that have increased and the order of increasing area in percentage over the last 40 years are as follows: lebak; lakes; rivers and tidal swamps with the following values in sequence are as follows $9.42 \%, 9.38 \%, 6.74 \%$, and $6.70 \%$ respectively. An area increase is induced by natural and human intervention. During the rainy season, other wetlands such as peatlands are flooded, so it becomes lebak and tidal swamps. This causes lebak and tidal percentage area has increased for the last 40 years.

Decreasing peatlands will be in the percentage of $-23.27 \%$ due to natural factors and human intervention. Peatlands often experience fires and floods. Fires occur during the dry season where the soil becomes dry, so does the vegetation on the peatlands. This situation triggers easy fire occurs. Fires on peatlands can also occur due to unintentional, but fatal consequences, where people often carelessly do land clearing by burning. On dry land and hot weather, the little flame coming from land clearing is getting bigger and surely spreading and widespread.

Another natural factor affecting the decline of peatlands is flood. Floods generally occur during the rainy season where the water drops in a large volume and lasts longer or even daily. This resulted in floods on peatlands. Peatlands are experiencing a very high water inundation to cause peatlands is not visible. In addition to fires and floods, the area of peatlands is also reduced due to the land conversion process. Many peatlands are undergoing land conversion, the average peatlands is transformed into plantation land. There are several plantation companies that use peatlands into plantations.

Unidentified wetlands also decreased by around $-29.06 \%$ due to human intervention factor. In 1990 humans did not yet have the capabilities and tools that could be used to identify wetlands. So the percentage of unidentified wetlands area at that time reached $10.77 \%$. However, development of the human era begins to learn and have the tools to identify wetlands. Currently humans have used many tools to identify wetlands like Drone. 
This tool is a tool developed by humans that can be used to see the state of land and land area effectively and efficiently.

An increase in the percentage of lake area around $9.38 \%$ is caused by human intervention factor. Humans do a lot of developments improving the welfare for the region. The lake is one of the natural beauties that much preferred by the community and as one of the center of family tourism. This condition becomes a potential to increase lake area for making the lake as a tourist attraction.

Lebak swamps belong to the largest freshwater wetlands and are increasingly widespread from year to year (around 9.42\%). Based on hydro topography, height and length of inundation, lebak swamps are divided into five typologies, namely shallow; pematang; middle; deep; and lebaklebung (Table 2). Management based on lebak typology alone cannot give optimal results. This typology approach is useful for agronomic purposes only, but it cannot be used for integrated land management because of the high and long standing factors varies depending on the season and the dynamics of hydrology. So it is not surprising that if lebak reclamation is very intensive, then lebak typology rapidly turns into other lebak typologies or wide composition of each typology quickly changed (Table 2).

Table 2. Lebak swamp typology and alternative uses

\begin{tabular}{|c|c|c|c|}
\hline \multirow{2}{*}{$\begin{array}{c}\text { Typology, their positions } \\
\text { \& area }\end{array}$} & \multirow{2}{*}{ Hydrological characters } & \multicolumn{2}{|c|}{ Landuse in seasons } \\
\hline & & Rain & Dry \\
\hline $\begin{array}{l}\text { Shallow (located along } \\
\text { embankment of rivers, } \\
\text { alluvial plains and flat } \\
\text { topography); } 25.23 \%\end{array}$ & $\begin{array}{c}\text { Very dynamic, flooded ( }<3 \\
\text { months/year) in rainy season, } \\
\text { inundation height }<25 \mathrm{~cm} \text {, and } \\
\text { dry in dry season) }\end{array}$ & $\begin{array}{l}\text { Rice, plantation, } \\
\text { livestock, } \\
\text { forestry, } \\
\text { industry, } \\
\text { housing }\end{array}$ & $\begin{array}{l}\text { Fallow, } \\
\text { forestry,plantati } \\
\text { on, livestock, } \\
\text { industry, } \\
\text { housing }\end{array}$ \\
\hline $\begin{array}{l}\text { Pematang (on } \\
\text { embankment of rivers, } \\
\text { river valley and flat } \\
\text { topography); } 18.78 \% \\
\end{array}$ & $\begin{array}{c}\text { Dynamic, flooded }<3 \\
\text { months } / \text { year, inundation } \\
\text { height } 25-50 \mathrm{~cm} \text {, and dry in } \\
\text { the dry season }\end{array}$ & $\begin{array}{l}\text { Rice, plantation, } \\
\text { livestock, } \\
\text { forestry }\end{array}$ & $\begin{array}{l}\text { Rice, forestry } \\
\text { plantation, } \\
\text { livestock, }\end{array}$ \\
\hline $\begin{array}{l}\text { Middle (on flood plains } \\
\text { and river valleys); } 22.02 \%\end{array}$ & $\begin{array}{c}\text { Dynamic, flooded 3-6 } \\
\text { months/year, and inundation } \\
\text { height } 50-100 \mathrm{~cm}\end{array}$ & Fishery & Rice, fallow \\
\hline $\begin{array}{l}\text { Deep (located next to } \\
\text { floodplain and basin); } \\
\qquad 21.79 \%\end{array}$ & $\begin{array}{c}\text { Less dynamic, flooded 6-9 } \\
\text { months/year, inundation } \\
\text { height } 100-150 \mathrm{~cm} \text {, and peat } \\
<50 \mathrm{~cm}\end{array}$ & Fishery, fallow & Fishery, fallow \\
\hline $\begin{array}{l}\text { LebakLebung (in deep } \\
\text { basin); } 12.18 \%\end{array}$ & $\begin{array}{l}\text { Static, always inundated, } \\
\text { inundation height }>150 \mathrm{~cm} \text {, } \\
\text { and peat } 50-100 \mathrm{~cm}\end{array}$ & Fishery, fallow & Fishery, fallow \\
\hline
\end{tabular}

Source: Field survey results (2018), Landsat images (1992; 2017)

Shallow lebak is very dynamic means that any lebakdevelopment will directly affect the extent of shallow lebak because lebak development has a direct impact on the increase of sedimentation which resulted in the widespread area of the flooded river basin. Because the nature is very dynamic, then shallow lebakarea can be smallest or widest. Another case with lebaklebung is static compared to middle lebak due to permanent and deep inundation.

\subsection{Biodiversity Loss}

Wetlands are under threat from reclamation, excessive drainage and irrigation, dam, building, pollution, excessive use of resources, biological invasion and global climate change. Their impacts are biodiversity loss, land and water pollution, overfishing, and 
sedimentation. This threat should be minimized to preserve the wetlands. Wetlands occupy only around $30 \%$ of the total area of South Sumatra Province, but are able to provide a large number of ecosystem services, including fresh water supplies, flood arrangements, wastewater purification, natural resources, wildlife habitats, and marine life preservation (Table 3).

Table 3. The predicted numbers of species living in wetlands of South Sumatra

\begin{tabular}{|c|c|c|c|}
\hline \multirow{2}{*}{ Taxon } & \multicolumn{2}{|c|}{ Numbers of species } & \multirow{2}{*}{$\begin{array}{c}\text { Losses } \\
(\mathbf{\%})\end{array}$} \\
\cline { 2 - 3 } & $\mathbf{1 9 9 0}$ & $\mathbf{2 0 1 7}$ & \\
\hline Natural Vegetation & & & -26.49 \\
\hline Gymnosperm & 268 & 197 & -10.11 \\
\hline Fern & 2.367 & 2.128 & -5.56 \\
\hline Moss & 2.249 & 2.124 & -9.43 \\
\hline Angiosperm & 31.000 & 28.077 & -9.37 \\
\hline Subtotal & 35.884 & 32.526 & \\
\hline Animals & & & -27.38 \\
\hline Fish & 3.017 & 2.191 & -14.25 \\
\hline Bird & 1.256 & 1.077 & -12.50 \\
\hline Mammal & 532 & 428 & -21.70 \\
\hline Reptilian & 318 & 249 & -21.03 \\
\hline Amphibian & 271 & 214 & -22.90 \\
\hline Subtotal & 5.394 & 4.159 & \\
\hline
\end{tabular}

Sources: Compiled from BPS (2015); Field survey results (2018); Google (2017);

Forestry Department (2015) and other literature

Gymnosperm. This population reduction is due to illegal logging by irresponsible parties. Gymnosperm especially acacia and pine trees are widely used for furniture, pulp and paper and common industry. Because of these, it is encouraging certain parties to do illegal logging without thinking about environmental sustainability.Fern population decline is due to people living around wetlands utilizing ferns for daily consumption of food and medicine. Since ferns commonly grow and live wildly in bushes or forest, people take ferns for free, thus why it population is decreasing.

Moss population reduction is due to the global warming effect. The growth of moss tends to be slower in dry and infertile areas because moss belongs to epiphytic vegetation that is less suitable to live it hot and dry places. The effect of global warming inhibits moss growth, so that the population is decreasing. Angiosperm is the largest group of vegetation and very important for human life because it is useful as a source of food for humans and animals. Some examples of angiosperm are fruits and flowers (such as mango, apple, tomato banana, durian, orange, orchid, sunflower, rice and others). Angiosperm is widely used as a source of human and animal food, land conversion to settlement and industry.

Fish populations decreased due to overfishing using poisonous and electrical illegal instruments. Global warming also affects the increase in temperature and increased acidity levels due to increased carbon dioxide. This has an impact on the decline of fish populations, because warming temperatures in the water will inhibit the growth of fish and even at risk of fish death. Throwing garbage carelessly into the waters is causing water pollution that threatens the life of fish inside.Amphibians decline populations is caused by the low availability of animal food resources in the form of small fish. Less source of food makes amphibians cannot meet their food needs affecting their inhibition of growth and development. The reduction in amphibian populations is also due to habitat destruction and climate change. 
Birds reduction population is due to the growing human activity damaging the bird habitats, for example land clearing of forest for settlements and industry where the forest is a natural habitat of birds, humiliation of birds and depletion of bird food stocks. In accordance with the order of the food chain if the amphibians or small fish are extinct, then the bird as a consumer will also go extinct because in general birds must eat at least half of their weight every day.Reptiles presence is very important in natural food networks as predators and prey. As reptile predators will prey on other animals such as fish, frogs and birds to support their survival. Reduced reptile food sources will certainly increase the risk of declining reptile populations. Reptile extinctions are also triggered by climate change threatening their existence as well as habitat destruction and excessive extraction for animal trade.Mammals belong to the generalist species eating many types of food are far more able to survive in a changing environment.

In addition, it increases the frequency of floods from once every five years or ten years. The loss of wetlands also resulted in the extinction of many species requiring wetlands as their vital habitat. Among known animal species that have been extinct in the last 50 years, most of them are wetlands species, including large head fish (Aspiorhynchuslaticeps), estuarine crocodiles (Crocodilusporosus), betook fish, tapa, tengkeleso, elephant and wild deer (Elaphurusdavidianus). Most extinction is caused by habitat loss due to wetlands damage. The disappearance of wild rice (Oryza meyeriana), which was found in the South Sumatra swamps of South Sumatra in the 1980s and used to create hybrid rice; These new crops increase rice production, but wild rice populations disappear from their natural environment. In addition to the direct destruction of wetlands, there are other issues related to the health and conservation of wetlands, such as water pollution, loss of $\mathrm{C}$ storage, and biological invasion. This problem is as bad as the loss of wetlands.

\subsection{Determinant Degradation Causes of Wetlands}

Many factors contributed to degradation of wetlands, including high population pressure on natural resources, lack of understanding of wetlands values, weak enforcement and legal compliance of inadequate policies, weak regulation and environmental regulations, excessive drainage and irrigation and rapid economic growth. Here, we discuss three major causes of wetlands loss over the years: reclamation, misguided policy and midlanduses, and excessive drainage and irrigation.

\subsubsection{Reclamation}

Reclamation is a major cause of loss of wetlands. Most reclamation has been going on for the last 40 years. Around 133.500 ha of wetlands have been used for plantations, agriculture, fish ponds, settlement and industry obtained from wetlands conversion. Overall, reclamation alone could reach $78 \%$ of total wetlands losses. If landscape of wetlands is evaluated, wetlands are expanding around $+32.24 \%$, while wetlands loss is about $-52.33 \%$, thus the total wetlands lost as much as $-20.09 \%$ for 27 years $(1990-2017)$ or about $0.74 \%$ per year due to erosion and soil compaction (Table 1). Most eroded soils are transported into general waters (rivers, sea, lakes, basins, valley and so on).

\subsubsection{Misguided Policy and Mislanduses}

The recovery capacity loss of wetlands is so high. It was primarily the result of reclamation policies supported by the government during the last 40 years. Efforts for food resilience is the main driving force of government reclamation policy, and large-scale reclamation by 
building embankments and water canals networks requires greater financial and labor support. Only the government can provide it. However, recent natural disasters bring the attention of governments and society to the severe environmental problems caused by the policy of economic growth by all means. The realization of the environmental consequences of misguided policies also leads to changes in attitudes toward the environment in general and wetlands in particular. As a result, large-scale reclamation is still permitted by the government, although wetlands and natural swamps are under threat from environmental impacts, as many local governments continue to regard them as potential wetlands resources for exploitation.

\subsubsection{Excessive Drainage and Irrigation}

Decreased groundwater levels are a major cause of loss of natural wetlands. Drainage development for plantation, agricultural and industrial development has led to a reduction in water flow to wetlands over the last 40 years. The drained wetlands area increased by around $340 \%$ from 1990 to 2017 , and most of the water was lost due to excessive drainage $(120-150 \%)$ and low irrigation efficiency (15-35\%). The excessive use of water by agriculture and other industries resulted in a low river flow at the bottom of the river having no water flow. Beside that around $75 \%$ of water dams and water gates do not function properly, thus they are not able to manage water according to plant needs and also disrupt the species migration route waters and finally alter the water fauna.

\subsection{Current Efforts to Protect Wetlands}

Wetlands are protected under a three-class system: wetlands reserves (full protection from development and human activities), wetlands parks (full protection from development, but used for ecotourism), and beautiful gardens (protection from development, but open to the public for recreation). Some important actions should be taken by the government in protecting, restoring, and creating wetlands:

\subsubsection{Peatland Restoration}

South Sumatra began to restore the degraded wetlands in early $2014 \mathrm{~s}$ by establishing Peat Restoration Agency (BRG). BRG functions are to protect and restore existing wetlands, to recover lost wetlands, and to tackle other wetlands problems. BRG do also how to restore the water quality of natural peatlands, and to restore pollution purification capacity in wetlands. The new policy has been made to restore some peatlands of reclaimed farms to wetlands or native peatlands, namely groundwater management; fish population conservation; and wetland reserves and restorations.

Groundwater management plans are implemented to improve water control in the fields and to protect wetlands, particularly to treat highly degraded wetlands. The action plan focuses on the control of point and nonpoint sources of problems, water management and water control by involving local society. In addition, many laws and regulations on water management has been enacted by national, provincial and local governments.

Regulations to ban or prohibit fishing in the reproductive period have been carried out, for example at the mouth of the river and fishing grounds. Action plans for restocking (replenishing) wetlands with fish seedlings from hatcheries have begun, including both commercial and endangered species of fish, have been released into common waters (lakes, rivers, tidal, and peatlands). Wetlands reserves consist of core areas, where human activity is prohibited to cultivate agriculture, and the areas are determined as buffering zones, where 
some human activities are only permitted by permission. The government began to build wetlands natural reserves in early 2000 s.

\section{Conclusions}

The results and discussion of this research can be drawn some conclusions as follows:Dominant wetlands in South Sumatra are namely lebak, tidal, rivers, lakes, peatlands, and unidentified. Lebak swamps belong to dominant wetlands changing dominantly each year followed by tidal swamps, rivers, and lakes while other types decrease continuously.Predicted species living in wetlands are decreasing in number; the most dominant decrease was experienced by fish, gymnosperm, mammal, reptilian, bird, amphibian, fern, angiosperm and moss respectively. The major causes of wetlands loss over the years are reclamation, misguided policy and mislanduses, and excessive drainage and irrigation. Current efforts to protect wetlands are peatland restoration, groundwater management, fish population and conservation and wetland reserves and restorations.

\section{Acknowledgments}

The authors would like to acknowledge the financial assistance provided by Universitas Sriwijaya along with the highly valued staff inputs at the Faculty of Agriculture of Universitas Sriwijaya. We would like to thank all students for their comments on early versions of this paper along with valuable feedback from anonymous reviewers.

\section{References}

1. Sarno, R.A. Suwignyo, Z. Dahlan, Munandar, M.R. Ridho, N. Aminasih, Harmida, M.E. Armanto, E. Wildayana. Biodiversitas 18, 3 (2017)

2. M.E Armanto,, M.A. Adzemi, E. Wildayana, M.S. Imanudin. J. of Sustainability Science and Management 8, 1 (2013)

3. M.E Armanto,. E. Wildayana. J. of Wetlands Environmental Managements 4, 1 (2016)

4. S.M. Lu. J. of Sustainable Development 103 (2017)

5. K. Fobissie, D. Etongo, M. Kanninen. Journal of Sustainable Development 10, 5 (2017)

6. E. Wildayana, M.E. Armanto. J. of Sustainable Development 11, 3 ( 2018)

7. E. Wildayana, M.E. Armanto. J. of Sustainable Development 11, 2 (2018)

8. M.E Armanto., M.S. Imanudin, E. Wildayana, H. Junediand M. Zuhdi. Sriwijaya Journal of Environment 1, 3 (2016)

9. E. Wildayana. J. of Agricultural Science 23, 6 (2017)

10. E. Wildayana, M.E. Armanto. Bulgarian Journal of Agricultural Science. 24, 2 (2018)

11. I. Zahri, D. Adriani, E. Wildayana, Sabaruddin, M.U. Harun, Bulgarian Journal of Agricultural Science. 24, 2 (2018) 